\title{
Valuation of the Aroeira (Myracrodruon urundeuva Allemão): perspectives on conservation
}

Julio Marcelino Monteiro ${ }^{1,2,5}$, Elcida de Lima Araújo ${ }^{3}$, Elba Lúcia Cavalcanti Amorim ${ }^{4}$ and Ulysses Paulino de Albuquerque

Recebido em 30/08/2011. Aceito em 16/01/2012

\section{RESUMO}

(Valoração da Aroeira (Myracrodruon urundeuva Allemão): Perspectivas para a conservação). Atribuir valor econômico a um dado recurso ambiental e avaliá-lo a níveis comparáveis com preços de mercado poderá auxiliar propostas para sua conservação e facilitar o estabelecimento de políticas ambientais. Assim, esta pesquisa estabelece um valor econômico para M. urundeuva Allemão, baseado na disposição máxima a pagar (DAP) das pessoas que freqüentam a feira de Caruaru, situada no Nordeste brasileiro, utilizando-se o método da Valoração Contingente. A maioria dos entrevistados concordou em participar de propostas para viabilizar a conservação da espécie, muito embora a DAP encontrada seja relativamente baixa, comparando-se a outros trabalhos conduzidos no Brasil. Muitos entrevistados apresentaram baixa renda mensal. Destaca-se o elevado número de pessoas ( $98,5 \%$ dos informantes) que demonstraram preocupação com a conservação da biodiversidade e muitos indicaram que a preservação da biodiversidade não é uma tarefa exclusiva do governo ou da sociedade, mas de todos juntos. Conseqüentemente, esta pesquisa pode incentivar, juntamente a outras pesquisas ou ações governamentais, o implemento de propostas públicas para a conservação ambiental financiada por uma sociedade que tenha a disposição a pagar. Este é o primeiro estudo de valoração econômica de uma espécie vegetal da caatinga que se configura em listas atuais de plantas ameaçadas de extinção.

Palavras-chave: Valoração contingente, Caatinga, Plantas medicinais

\begin{abstract}
(Valuation of the aroeira (Myracrodruon urundeuva Allemão): Perspectives on conservation). Assigning an economic value to a given environmental asset has helped conservation proposals, and valuing these assets at levels comparable to market rates facilitates the establishment of environmental policies. Thus, this research aimed to assess the value of the species Myracrodruon urundeuva Allemão, using the method of contingent valuation to determine the maximum willingness to pay of frequent visitors to the Caruaru Fair, located in northeastern Brazil. Our results show that most interviewees agreed to participate in proposals to support species conservation, although the average willingness to pay (WTP) was relatively low compared to other surveys conducted in Brazil. However, a significant number of the interviewees had exceptionally low monthly incomes. Another relevant aspect of this research was the high number of people ( $98.5 \%$ of the informants) who were concerned about biodiversity conservation; many interviewees stated that the preservation of biodiversity is not a duty exclusive to the government or the people but rather a collective responsibility. Therefore, these findings may encourage the provision of public proposals for environmental conservation, along with other surveys or government actions funded by a society that has the willingness to pay for them. This study is the first economic valuation of a caatinga species, many of which are under threat of extinction.
\end{abstract}

Key words: Contingent valuation, Caatinga, Medicinal plant

\footnotetext{
1 Universidade Federal Rural de Pernambuco, Departamento de Biologia, Área de Botânica, Laboratório de Etnobotânica Aplicada, Recife, PE, Brazil 2 Universidade Federal do Piauí, Departamento de Biologia,. Campus Profa. Cinobelina Elvas, Bom Jesus, PI, Brazil

3 Universidade Federal Rural de Pernambuco, Departamento de Biologia, Área de Botânica, Laboratório de Ecologia Vegetal e Ecossistemas Naturais, Recife, PE, Brazil

4 Universidade Federal de Pernambuco, Centro de Ciências da Saúde, Departamento de Ciências Farmacêuticas, Recife, PE, Brazil

5 Author for correspondence: juliommonteiro@ufpi.edu.br
} 


\section{Introduction}

Natural resources are finite and exhaustible, and many researchers, particularly environmental economists, have proposed tools to assess these resources. The assignment of an economic value to a given environmental asset allows for that asset to be evaluated according to its market price, thus facilitating the establishment of environmental policies (Edwards \& Abivardi 1998; Nogueira \& Medeiros 1999; Mota 2001; Ortiz 2003). Concepts such as sustainable development ${ }^{6}$ have dominated academic discourses and have helped identify and avoid the risks of excessive and inordinate use of environmental assets, particularly in the case of non-renewable resources (Mota 2001; Romeiro 2003). In environmental economics, the total economic value of a resource can be divided into the basic categories of use and non-use value. Use value refers to the value of extraction or consumption and can be further divided into either the direct or indirect use of a resource. Indirect use refers to the indirect ownership of a certain resource, such as the appreciation of the landscape's beauty. Non-use value, also known as intrinsic value or existence value, refers to the personal satisfaction generated by a resource, regardless of its present use or the possibility of its future use (Motta 2006; Mattos et al. 2007).

The contingent valuation method (CVM) captures the existence value of the resource by measuring people's willingness to pay (WTP) a variable sum of money for the recovery or preservation of a particular environmental asset (Nogueira \& Medeiros 1999; Mota 2001; Moura 2003; Ortiz 2003; Mattos \& Mattos 2004; Venkatachalam 2004; Motta 2006; Máximo et al. 2009). Several researchers around the world have utilized contingent valuation to estimate the economic value of parks, forests and even biological species (Bandara \& Tisdell 2004; Bateman \& Mawby 2004; Amirnejad et al. 2006; Montgomery \& Helvoigt 2006; MartaPedroso et al. 2007; Salttout et al. 2007). This methodology has also been applied to evaluate resources in Brazil and thus can help facilitate the implementation of conservation projects (Braga \& Abdallah 2003; Fonseca \& Drummond 2003; Fernandez \& Kuwahara 2005; Pereira \& Campos 2005; Adams et al. 2008; Máximo et al. 2009).

In this study, the contingent valuation method was used to assess the value of the aroeira tree (Myracrodruon urundeuva Allemão) based on the maximum willingness to pay (WTP) of frequent visitors to the Caruaru Fair, located in northeastern Brazil, who are familiar with the plant. This species was chosen because it is well known and is frequently used by the local population. It is also currently listed as an endangered species (MMA 2008). This medicinal plant provides both formal and informal trade value in the metropolitan area of the Pernambuco state capital, as well as elsewhere in the state (Albuquerque et al. 2007; Melo et al. 2009). Additionally, interviewees' opinions about issues concerning biodiversity conservation were collected and discussed.

\section{The "wilderness aroeira" (Myracrodruon urundeuva Allemão)}

The aroeira tree is a member of the plant family Anacardiaceae and is widespread throughout the northeastern territory of Brazil and some states in the South, Southeast and Central-Western Regions. The term 'aroeira' is a combination of the words arara (macaw) + erira, meaning macaw tree (Brandão 1992). There are numerous other, regionally specific names for this tree, including urundeuva, urindeuva, and pandeiro e aroeira-preta in São Paulo and Minas Gerais; urunday and aroeira-preta in Mato Grosso; urundel in Argentina; and urundei-mi e urunde'i in Paraguay (Brandão 1992).

The tree can reach 20 meters in height and is characterized by a single straight, cylindrical trunk. Young aroeira trunks have a dark brown cortex and lenticels. The leaves are deciduous, alternate, compound, membranaceous and glabrous to pilose with simple trichomes. The petioles are cylindrical and the leaflets are opposite. Its inflorescences are terminal or axillary and paniculate, with pentamerous, diclinous flowers contained in a perianth. Sepals are membranaceous and elliptic, and the corolla is dialipetal with imbricated prefloration. The androecium consists of five free stamens and the syncarpous gynoecium. The tree also has a drupe-type fruit (Santin \& Leitão 1991).

Aroeira is highly exploited as a source of timber, fuel and medicine in the semi-arid northeast region of Brazil; however, most studies have focused on the latter use (Albuquerque \& Andrade 2002; Monteiro et al. 2006; Lucena et al. 2008, Ramos et al. 2008). Popular medicine indicates the use of aroeira as an external treatment in "sitz" baths against uterine inflammation, and it is used in mouthwash to prevent mouth and throat infections. It is also prescribed for the treatment of wounds in which a decoction or hydroalcoholic tincture is prepared from the bark. Monteiro et al. (2006) found a large number of citations on this plant's medicinal uses, including general anti-inflammation and healing properties.

This species has high concentrations of phenolic compounds, especially tannins, and a number of studies have demonstrated the therapeutic qualities of these compounds (Chaves et al. 1998; Morais et al. 1999; Queiroz et al. 2002; Viana et al. 2003; Monteiro et al. 2006). Dimeric chalcones isolated from M. urundeuva Allemão showed analgesic and anti-inflammatory activities in rats (Viana et al. 2003). The popular use of aroeira against diarrhea was confirmed to be effective in a rat model by Chaves et al. (1998), and

\footnotetext{
6 According to Romeiro (2003), the term sustainable development came from ecodevelopment and is consensually attributed to Ignacy Sachs, from the School of Advanced Studies in Social Sciences. It can be defined as a type of activity that meets the current demands of the people without necessarily compromising the future needs of that population.
} 
this evidence may justify further studies with humans. In addition, a methanol extract from the bark reduced DNA oxidation, suggesting that it is a potent antioxidant (Desmarchelier et al. 1999).

Due to its significant importance as a medical and timber resource, this plant has been identified as a priority species for conservation (Vieira et al. 2002). In addition to the current list prepared by the Ministério do Meio Ambiente (MMA 2008), M. urundeuva Allemão is also on the list of endangered plants that was developed by the Instituto Brasileiro do Meio Ambiente e Recursos Naturais Renováveis (IBAMA 2008). Aroeira was classified as vulnerable due to predatory exploitation practices and its potential for extinction. In a review of the species, Leite (2002) identified several locations that urgently require conservation efforts, including the transition between the Amazon Forest and the Caatinga (Tocantins to Maranhão). The author mentions that even areas currently protected by conservation measures require greater supervision due to aggressive exploitation practices. Several ethnobotanical studies of the semi-arid areas of Pernambuco in Northeast Brazil have identified priority species for conservation, including aroeira (M. urundeuva Allemão). In addition to the intense demands of timber and fuel use, aroeira is threatened by the aggressive bark collection techniques used to meet the demands of both small and large pharmaceutical industries as well as for trade in local markets and fairs (Oliveira et al. 2007; Albuquerque et al. 2008a,b; Melo et al. 2009).

\section{Material and methods}

\section{Study area}

The municipality of Caruaru $\left(8^{\circ} 14^{\prime} 19^{\prime \prime} \mathrm{S}, 35^{\circ} 55^{\prime} 17^{\prime \prime} \mathrm{W}\right)$ is located in the Agreste region of Pernambuco, in the Ipojuca Valley. Caruaru is approximately $130 \mathrm{~km}$ from the state capital Recife, in northeastern Brazil (IBGE, 2008). The climate is semi-arid, with an average annual temperature of approximately $22^{\circ} \mathrm{C}$ and an average annual rainfall of 609 $\mathrm{mm}$. The rains are distributed between May and August (IBGE 2008).

The vegetation is predominantly xerophytic and is marked by seasonal change, as the short rainy period results in a semi-arid climate (Rodal \& Sampaio 2002). This study was conducted in the Caruaru Fair, located in Parque 18 de Maio. This fair is used for the grocery trade and features items such as flour or beans, crafts, shoes, clothing and medicinal herbs (Prefeitura de Caruaru 2008). The sale of traditional medicinal plants occurs from 8 am to $5 \mathrm{pm}$, Monday through Saturday, with 17 vendors.

Tuesdays and Saturdays are the busiest days at the fair. On Tuesday, fabrics and clothing are sold at the famous Sulanca fair, which has approximately 10,000 registered vendors and receives, on average, 400 busloads of visitors and 40,000 people from the region and its surrounding cities (Municipality of Caruaru 2008). On Saturday, food and vegetable seasonings are sold. Attendance is largest in the morning, with the number of visitors decreasing in the evening.

On February $7^{\text {th }}, 2007$, the fair received the title of "Patrimônio Cultural Imaterial do Brasil" from the Instituto do Patrimonio Historico e Artistico Nacional (IPHAN 2008). The fair was granted this title because of the varied expressions of traditional knowledge on display there, including the use of medicinal plant species, the artistic merit of the crafts, the diversity of northeastern Brazilian cuisine, the presence of regional agricultural products and the preservation of family farming practices (IPHAN 2008).

In general, the characteristics of each market are determined by its size, frequency and location (Cunningham 2001). The Caruaru Fair is considered to be a permanent market, as it is surrounded by a large urban center and has a regular weekly schedule, closing only on Sundays.

\section{Sample selection}

The population investigated in this study consisted of consumers of medicinal plants at the Caruaru Fair. People circulating the area for the sale of medicinal plants were considered to be consumers. The location of the medicinal plant stalls favored this research design, as all of the medicinal plant traders are concentrated in two blocks separated from the other areas of the fair.

As there is no defined size for the population studied, the sample was characterized as a floating population, and the sampling type was accidental (Albuquerque et al. 2008b). Counts of people circulating in the medicinal plant area were carried out during the two days of greatest traffic: Tuesday and Saturday.

The counts were conducted as follows. Two researchers were positioned at the ends of each block, totaling four people. Each researcher counted all of the people who entered the block where they were positioned. The researchers closest to each other worked cooperatively to prevent counting the same person twice. On the two days selected for sampling, counts were conducted from 9 am until 11 am and continued from $12 \mathrm{pm}$ to $2 \mathrm{pm}$ before being finalized from $3 \mathrm{pm}$ to $4 \mathrm{pm}$. Preference was given to the morning period, given that the greatest number of people was present at this time. By the end of these counts, 437 people had been observed on Tuesday and 646 on Saturday. Therefore, an average of 541 people passed through the area per day, leading to an estimated 169,333 visitors per year. Sundays were excluded from this average, given that the fair is closed on this day. Based on the calculations described and considering a confidence interval of $5 \%$, it was estimated that a minimum sample size of 399 people would be sufficient; however, a total of 613 interviews were conducted. The decision to use a higher value was due to the type of sample (accidental, non-probabilistic), which is less robust than probabilistic sampling. 
All 613 interviews were performed on Saturdays, given that this day had the highest rate of attendance, and were held between November 2007 and May 2008. Before the beginning of each interview, the interviewee was asked whether he/she knew about the aroeira tree. Knowledge of the plant, regardless of whether the interviewee had used it, was essential for participating in the interview, as some authors argue that a lack of knowledge on the resource in question may lead to inaccurate results (Sanchez \& Perez 2000; Fonseca \& Drummond 2003; Mattos \& Mattos 2004; Kniivila 2006).

\section{Method of valuation and interview form}

Every natural resource has an intrinsic value and can also be given a monetary, market-based value, and this latter method facilitates decision making related to the use of environmental resources (Ortiz 2003). Such methods of economic valuation were primarily used by economists but are now being used to guide decision making related to the sustainable use of environmental resources (Motta 2006). This study adopts the contingent valuation method (CVM), which is recognized as the most common and effective method of environmental valuation available (Ortiz 2003; Motta 2006; Marta-Pedroso et al. 2007; Sattout et al. 2007). The current study sought to determine the individual preferences of medicinal plant consumers at the Caruaru Fair regarding the aroeira tree by estimating their willingness to pay (WTP) for its conservation. This value indicates a relative willingness to adopt protection policies for the tree in question. The contingent valuation simulates a hypothetical market scenario in which the interviewees maximum willingness to pay (WTP) for a particular environmental asset can be determined (Ortiz 2003; Motta 2006; Marta-Pedroso et al. 2007; Sattout et al. 2007). This research instrument was designed to be as realistic as possible and thus capture a more reliable WTP value (Nogueira \& Medeiros 1999; Sanchez \& Perez 2000; Aguirre et al. 2002; Fonseca \& Drummond 2003; Mattos \& Mattos 2004).

Semi-structured interviews were conducted using a form with predefined questions. A pre-test was performed with 20 interviewees in the study location to verify the ease of understanding and clarity of the form. The interview form was divided into three parts. The first part contained questions about the socioeconomic status of the interviewees. The second part addressed the formulation of the hypothetical market by focusing on questions that tested the subject's knowledge of the species. This hypothetical scenario is formulated to emphasize the current status of the resource environment and the importance of its conservation. Thus, the maximum willingness to pay (WTP) reflected the views of respondents. The third part of the interview was used to collect the interviewees' opinions on biodiversity conservation.

First, the importance of this species and its various uses were presented to the interviewee, and this was followed by a question. The survey read as follows: The Aroeira plant is widely known and used by the people of the Northeast. Its wood is used as firewood and to build houses and fences. It is also widely used to treat injuries such as scarring, as an antibiotic, and in the treatment of gastritis and general inflammation. However, this tree may disappear from the forest if adequate care is not taken. Do you think that this plant should be conserved? After the subject provided an answer, the following question on resource valuation was given: Considering all of your expenses and those of the people who live with you, including food, transportation, education, health, and leisure, how much would you be willing to voluntarily pay per year to preserve the Aroeira, knowing that the money would be applied correctly?

The question was open-ended, and thus the interviewee was not limited to pre-defined values. Thereafter, the interviewee was asked how they would like to make their payment. Payment vehicles included bank accounts, light or water invoices, a collector to retrieve the amount from the residence, a credit card or a payment made directly to the conservation organization. The number of interviewees who answered each question was organized according to their position in favor of (WTP) or in opposition to (not WTP) the species valuation proposal.

\section{Data analyses}

Differences in WTP were compared between sex, age groups, income classes, marital status, family size, occupation and education level, as well as among those who had used the plant and those who had not or could not remember, and also between the frequencies of interviewees who expressed opinions on biodiversity conservation. These differences were verified by the Kruskal-Wallis test using the software Bioestat 5.0 (Ayres et al. 2007). The ranges of classes described above for age, income, marital status, family size, occupation and education level were modified from Motta (2006).

\section{Results and discussion}

\section{Socioeconomic profile of respondents and their willingness to pay}

A total of $261(42.5 \%)$ women and $352(57.5 \%)$ men were interviewed. All 613 interviewees were familiar with the aroeira, $423(68.8 \%)$ people confirmed that they had made some use of it, 187 (30.6\%) did not use it and 3 $(0.4 \%)$ reported that they could not remember if they had used the plant for any purpose in the past. A total of 466 (75.8\%) people indicated that they were only aware of the species' medicinal uses, while the remaining 147 (24.2\%) were aware of the other uses for the plant, such as fuel or construction. Some authors have argued that the resource should be used or at least known by the target population in the study (Sanchez \& Perez 2000; Fonseca \& Drummond 2003; Kniivila 2006). 
Corresponding to the revealed importance of the plant, 98.5\% of informants reported that the species should be conserved. When questioned whether systematic use, due to the variety of uses for the plant, could lead to the extinction of the tree, 490 (80\%) people responded affirmatively, while 113 indicated that the plant would never become extinct, and 10 were unable to respond. Accordingly, 491 people (80.1\%) had an average WTP of R 40.32 (standard deviation $\pm R \$$ 100.80) per year for the conservation of the aroeira tree. The minimum WTP was $\mathrm{R} \$ 0.50$, and the maximum was $\mathrm{R} \$$ $1,000.00$. No significant differences were found between the WTP of interviewees who reported use of the plant $(N=355$; average $\mathrm{WTP}=\mathrm{R} \$ 30.56 \pm 60.13)$ compared to those who had not used it or did not remember $(N=136$; average WTP $=$ $\mathrm{R} \$ 42.28 \pm 79.9 ; \mathrm{H}=1.79, p=0.18$ ). Kniivila (2006) reported similar results for a study performed in Ilomantsi, Finland, finding that there were no significant differences between users and non-users of the resources assessed and showing that use did not indicate a higher WTP when compared to a simple knowledge of the resource.

In recent years, many researchers have used the contingent valuation method to estimate the monetary value of biological resources, such as ecosystems or species. In a study on the forests of Iran, Amirnejad et al. (2006) found that people would pay on average U\$ 30.12 per year to support management proposals. Several other authors have also sought to assign economic value to biological species (White et al. 2001; Montgomery \& Helvoigt 2006). In a study located in North Yorkshire, Canada, White et al. (2001) quantified the public's WTP for an action plan involving the conservation of the red squirrel (Sciurus vulgaris L.), the brown hare (Lepus europaeus Pallas), the otter (Lutra lutra L.) and the dormouse (Arvicola terrestris L.). In a study to determine the monetary value of cedar forests (Cedrus lebanon A. Rich.), Sattout et al. (2007) reported an average WTP of U\$ 42.43. Some authors have also used the method to value environmental assets in Brazil. For example, Mattos et al. (2007) assessed the Permanent Preservation Area in the Ribeirão São Bartolomeu watershed and reported an average WTP of $\mathrm{R} \$ 27.98$ per month among respondents. Fonseca and Drummond (2003) reported that a sample of local residents would be willing to pay approximately $\mathrm{R} \$$ 12.53 per month for the conservation of Laguna de Itaipu, in Niterói, RJ. The relatively low values of WTP found in this study (when compared to the above research) may be due to the low purchasing power of most of the interviewees (Table 1). However, the number of people willing to pay for a conservation proposal was high when compared to other studies (Hildebrandt et al. 2002; Fonseca \& Drummond 2003; Kniivila 2006; Mattos et al. 2007). Few authors have obtained results for WTP close to $80 \%$ in their research (Braga \& Abdallah 2003; Amirnejad et al. 2006).

Several different payment forms were chosen by the informants: 188 people preferred to pay through their bank account, 148 suggested that the amount be added to their light or water bills, 136 preferred that a collector retrieve the payment from their residence, one informant wished to pay by credit card, another preferred to pay the conservation organization directly and 16 were unable to answer. Some authors have used pre-determined vehicles to create the hypothetical market for resource conservation and restoration projects, such as an increase in the rates for water use (Mattos et al. 2007; Adams et al. 2008). Choosing a pre-determined payment vehicle can influence the public's WTP, as some individuals may not accept the additional fee on a given monthly expense. Researchers must understand and adapt to localized conditions such as this during a pilot initiative.

No significant differences were found between the mean WTP of sexes and socioeconomic categories of informants (Table 1), except between the mean WTP of single (also including separated or divorced) and married people $(\mathrm{H}$ $=8.66, p<0.05)$ and between the age groups of 18 to 25 years and more than 55 years $(\mathrm{H}=4.60, p<0.05)$ (Table 1$)$. These results showed that married and older people were less inclined to commit a portion of their income to the conservation of the species in question.

It was expected that people with higher incomes and levels of education would have a higher WTP relative to interviewees with lower levels of these variables. However, in contrast to these expectations, interviewees with higher income and education presented no statistical difference in their WTP for this proposal compared to people with lower incomes or levels of education. A majority (70.5\%) of interviewees with higher levels of education (complete or incomplete) affirmed that the role of government is weak or very weak with respect to environmental conservation in Brazil. Mattos et al. (2007) reported similar results and argued that this response is a form of protest and therefore bias. However, differing results have been found in some studies (Mattos et al. 2007). Mattos et al. (2007) reported that as income rises, WTP is likely to increase as well, indicating that people with a higher income demand improvements in environmental quality. In contrast, both Mattos et al. (2007) and Silva and Lima (2004) found no significant relationships between education and WTP.

A total of 122 people indicated no WTP. A significant portion of these people have a low education level, are more than 55 years old, are married, employed, receive between one and three times the minimum wage and have between three to five people in their residence (Table 2). The reasons for non-payment and the respective number of interviewees were as follows: cannot pay (65), the plant does not need to be conserved (19), believe that it is the government's responsibility (17), do not support resource management (16) and unable to respond (5). Of these interviewees, $90.3 \%$ reported receiving less than the minimum wage or up to three times the minimum wage, thus indicating the main reason for their unwillingness to pay for the conservation of aroeira. 
Table 1. Socio-economic profile of the interviewees in the Caruaru Fair, Northeast Brazil, that were willing to pay (WTP) to preserve the Aroeira (Myracrodruon urundeuva Allemão).

\begin{tabular}{|c|c|}
\hline Education & $\begin{array}{l}\text { Number of interviewees } \\
\left(\text { average } \mathrm{WTP}^{*} \pm \mathrm{SD}\right)\end{array}$ \\
\hline Illiterate & $73(29.6 \pm 55.72) \mathrm{a}$ \\
\hline Basic incomplete & $261(34.4 \pm 69.88) \mathrm{a}$ \\
\hline Basic & $41(23.6 \pm 43.4) \mathrm{a}$ \\
\hline Middle incomplete & $24(42.8 \pm 77.07) \mathrm{a}$ \\
\hline Middle & $65(39.4 \pm 80.58) \mathrm{a}$ \\
\hline Superior Incomplete & $10(47.0 \pm 39.94) \mathrm{a}$ \\
\hline Superior & $18(24.5 \pm 26.73) \mathrm{a}$ \\
\hline \multicolumn{2}{|l|}{ Number of people in residence } \\
\hline One or two people & $118(34.4 \pm 70.95) \mathrm{a}$ \\
\hline Three to five people & $163(32.6 \pm 61.07) \mathrm{a}$ \\
\hline More than five people & $56(39.8 \pm 65.7) \mathrm{a}$ \\
\hline \multicolumn{2}{|l|}{ Income $^{*}($ minimum wage $=R \$ 380.00)$} \\
\hline Less than a minimum wage & $125(32,5 \pm 66,05) \mathrm{a}$ \\
\hline One to three & $316(35,4 \pm 71,00) \mathrm{a}$ \\
\hline Three to five & $45(29,0 \pm 30,37) \mathrm{a}$ \\
\hline More than five & $6(16,0 \pm 12,56) a$ \\
\hline \multicolumn{2}{|l|}{ Age } \\
\hline 18 to 25 years & $54(51,3 \pm 114,19) \mathrm{a}$ \\
\hline 26 to 35 years & $106(36,0 \pm 63,44) \mathrm{ab}$ \\
\hline 36 to 45 years & $115(29,8 \pm 81,85) \mathrm{ab}$ \\
\hline 46 to 55 years & $95(42,5 \pm 45,24) \mathrm{ab}$ \\
\hline More than 55 years & $119(22,0 \pm 32,37) b$ \\
\hline \multicolumn{2}{|l|}{ Occupation } \\
\hline Retired & $54(24,3 \pm 37,5) \mathrm{a}$ \\
\hline Employed & $344(35,1 \pm 69,7) \mathrm{a}$ \\
\hline Unemployed & $93(24,5 \pm 30,75) \mathrm{a}$ \\
\hline \multicolumn{2}{|l|}{ Marital Status } \\
\hline Married & $277(27.3 \pm 46.27) \mathrm{a}$ \\
\hline Widower & $32(18.2 \pm 28.26) \mathrm{ab}$ \\
\hline Single (including divorced or separated) & $182(40.2 \pm 82.52) \mathrm{b}$ \\
\hline
\end{tabular}

Averages followed by distinct letters differ statistically at a 5\% interval of confidence.

* The willingness to pay (WTP) was measured in Reais (R\$).

\section{Opinion of the interviewees regarding biodiversity conservation}

Table 2 provides the results for the interviewees' opinions on biodiversity conservation. The sample was divided according to their position in favor of (WTP) or against (not WTP) using economic valuation as a mechanism for the conservation of the aroeira tree.

Table 3 provides a profile of the interviewees distributed among the study variables. Those who did not support a valuation scheme have similar concerns over environmental conservation as those who agreed to the proposal. In the first question, more than half of the sample revealed that they follow issues related to the environment, whether by print or audiovisual media. A total of 243 interviewees (slightly less than half) reported that nature conservation is not the exclusive responsibility of the government or the people, but is rather the responsibility of both parties. A total of $18 \%$ of those supported a WTP scheme, and $27 \%$ of those who did not believed that the government was solely responsible for environmental conservation. Thus, the majority of those
Table 2. Socio-economic profile of the interviewees in Caruaru Fair, Northeast Brazil, who were not willing to pay (not WTP) to preserve the Aroeira (Myracrodruon urundeuva Allemão).

\begin{tabular}{|c|c|}
\hline Education & Number of interviewees \\
\hline Illiterate & 39 \\
\hline Basic incomplete & 53 \\
\hline Basic & 7 \\
\hline Middle incomplete & 3 \\
\hline Middle & 12 \\
\hline Superior Incomplete & - \\
\hline Superior & 8 \\
\hline \multicolumn{2}{|l|}{ Number of people in residence } \\
\hline One or two people & 34 \\
\hline Three to five people & 80 \\
\hline More than five people & 8 \\
\hline \multicolumn{2}{|l|}{ Age } \\
\hline 18 to 25 years & 6 \\
\hline 26 to 35 years & 14 \\
\hline 36 to 45 years & 26 \\
\hline 46 to 55 years & 28 \\
\hline More than 55 years & 48 \\
\hline \multicolumn{2}{|l|}{ Marital Status } \\
\hline Married & 70 \\
\hline Widower & 11 \\
\hline Single (including divorced or separated) & 41 \\
\hline \multicolumn{2}{|l|}{ Occupation } \\
\hline Retired & 29 \\
\hline Employed & 88 \\
\hline Unemployed & 5 \\
\hline \multicolumn{2}{|l|}{ Income $^{*}($ minimum wage $=\mathrm{R} \$ 380,00)$} \\
\hline Less than a minimum wage & 34 \\
\hline One to three & 80 \\
\hline Three to five & 7 \\
\hline More than five & 1 \\
\hline
\end{tabular}

interviewed recognized their potential as agents of conservation. Adams et al. (2008) also found that a majority of their study participants were concerned about environmental issues in their country and felt that the government was not as concerned as it should be.

In the third question, $82 \%$ of interviewees who expressed a WTP stated that the environmental conservation efforts of their leaders were regular to very weak. Most of the interviewees who did not support a WTP scheme indicated that the actions of the government were good to regular. Finally, there was a broad consensus among the interviewees supporting the existence of conservation areas protected by law (Table 3 ). Similar results were found in a study by Adams et al. (2008), where the majority of interviewees also supported the protection of natural areas.

\section{Conclusions}

This study is the first proposal for the economic valuation of a caatinga species, which is threatened with extinction. Valuation proposals that emphasize resources widely 
Table 3. Profile of interviewees in the Caruaru Fair, Northeast Brazil, on issues directed to biodiversity conservation. The number of informants who answered each question was divided according to their position in favor (WTP - 491 interviewees) or against (not WTP - 122 interviewees) the valuation proposal of Aroeira (Myracrodruon urundeuva Allemão).

\begin{tabular}{|c|c|c|c|}
\hline \multirow{2}{*}{ Questions } & \multirow{2}{*}{ Answers } & \multicolumn{2}{|c|}{ Total (\%) } \\
\hline & & WTP & Not-WTP \\
\hline \multirow{5}{*}{ 1. Do you track issues related to the environment? } & Never & $85(17.3)$ & $32(26.2)$ \\
\hline & Rarely & $71(14.4)$ & $17(13.9)$ \\
\hline & Sometimes & $166(33.8)$ & $38(31.1)$ \\
\hline & Several times & $32(6.5)$ & $09(7.4)$ \\
\hline & Always & $137(27.9)$ & $26(21.3)$ \\
\hline \multirow{4}{*}{$\begin{array}{l}\text { 2. In your opinion, who is primarily responsible for environmental } \\
\text { conservation in Brazil? }\end{array}$} & Government & $89(18.1)$ & $34(27.9)$ \\
\hline & Population & $143(29.1)$ & $25(20.5)$ \\
\hline & Both & $243(49.4)$ & $57(46.7)$ \\
\hline & Do not know & $16(3.3)$ & $06(4.9)$ \\
\hline \multirow{5}{*}{$\begin{array}{l}\text { 3. In your opinion, how is the government's performance in preserving the } \\
\text { environment in Brazil? }\end{array}$} & Very weak & $91(18.5)$ & $16(13.1)$ \\
\hline & Weak & $139(28.3)$ & $27(22.1)$ \\
\hline & Regular & $173(35.2)$ & $37(30.3)$ \\
\hline & Good & $81(16.5)$ & $38(31.1)$ \\
\hline & Very good & $07(1.4)$ & $04(3.3)$ \\
\hline \multirow{5}{*}{$\begin{array}{l}\text { 4. In your opinion, how is the state of conservation of the environment in } \\
\text { Brazil? }\end{array}$} & Very bad & $74(15.0)$ & $16(13.1)$ \\
\hline & $\mathrm{Bad}$ & $166(33.8)$ & $30(24.6)$ \\
\hline & Reasonable & $200(40.7)$ & $43(35.2)$ \\
\hline & Good & $46(9.3)$ & $31(25.4)$ \\
\hline & Very good & $05(1.0)$ & $02(1.6)$ \\
\hline \multirow{3}{*}{$\begin{array}{l}\text { 5. What is your opinion on the existence of forest areas protected by law, } \\
\text { and that nobody can touch, or even fell a tree? }\end{array}$} & Favor & $446(90.7)$ & $110(90.2)$ \\
\hline & Against & $43(8.7)$ & $09(7.4)$ \\
\hline & Do not know & $02(0.4)$ & $03(2.5)$ \\
\hline \multirow{3}{*}{$\begin{array}{l}\text { 6. Finally, we would like to know what is the understanding difficulty of the } \\
\text { questionnaire you've just answered? }\end{array}$} & Easy & 485 (98.6) & $120(98.4)$ \\
\hline & Difficult & $04(0.8)$ & $01(0.8)$ \\
\hline & Do not know & $02(0.4)$ & $01(0.8)$ \\
\hline
\end{tabular}

used by the public, such as aroeira, may contribute to the development of valuation research and consequently assist in the sustainable management of resources.

The results showed that most interviewees supported the proposed valuation scheme for species conservation, although the mean value of the WTP may be considered low when compared to other surveys performed in Brazil. However, a significant portion of the study population had a low income or was experiencing other economic restrictions.

Another relevant aspect in this research was the large number of people who are concerned about biodiversity conservation and believe that preservation is a collective responsibility and not the exclusive task of the government or the public.

\section{Acknowledgements}

We would like to thank all of the study participants and would like to recognize the support offered by our team of interviewers: Sarahbele Cartaxo, Leila Dutra, Gustavo Soldati, Nelson Alencar, Reinaldo Lucena, Ernani Lins Neto, Thiago Araújo, Taline Silva, Flávia Silva, Tadeu Peixoto, Alyson Almeida and Patrícia Medeiros. We would also like to thank the CNPq for their financial support ("Edital Universal") and the U.P. Albuquerque for their generous grant.

\section{References}

Adams, C.; Motta, R.S; Ortiz, R.O.; Reid, J.; Aznar, C.E. \& Sinisgalli, P.A.A. 2008. The use of contingent valuation for evaluating protected areas in the developing world: Economic valuation of Morro do Diabo State Park, Atlantic Rainforest, São Paulo State (Brazil). Ecological Economics 66: 359-370.

Aguirre, A.; Faria, D.M.C.P.; Suyama, E. \& Santos, G.A. 2002. Redução dos custos de quantificação de benefícios na avaliação contingente. Revista Brasileira de Economia 56: 377-396.

Albuquerque, U.P. \& Andrade, L.H.C. 2002. Conhecimento botânico tradicional e conservação em uma área de caatinga no Estado de Pernambuco, Nordeste do Brasil. Acta Botanica Brasilica 16: 273-285.

Albuquerque, U.P.; Monteiro, J.M.; Ramos, M.A. \& Amorim, E.L.C. 2007. Medicinal and magic plants from a public market in northeastern Brazil. Journal of Ethnopharmacology 110: 76-91.

Albuquerque, U.P.; Araújo, T.A.S.; Ramos, M.A.; Nascimento, V.T.; Lucena, R.F.P.; Monteiro, J.M.; Alencar, N.L. \& Araújo, E.L. 2008a. How ethnobotany can aid biodiversity conservation: reflections on investigations in the semi-arid region of NE Brazil. Biodiversity and Conservation 18: 127-150.

Albuquerque, U.P.; Lucena, R.F.P. \& Lins-Neto, E.F.M. 2008b. Seleção e escolha dos participantes da pesquisa. Pp. 21-41. In: Albuquerque, U.P.; Lucena, R.F.P. \& Cunha, L.V.F.C. Métodos e Técnicas na Pesquisa Etnobotânica. 2 Ed. Recife. Comunigraf Editora/NUPEEA.

Amirnejad, H.; Khalilian, S.; Assareh, M.H. \& Ahmadian, M. 2006. Estimating the existence value of North forest of Iran by using a contingent valuation method. Ecological Economics 58: 665-675.

Arrow, K.; Solow, R.; Portney, P.R.; Learner, E.E.; Radner, R. \& Schuman, H. 1993. Report of the NOAA panel on contingent valuation. Federal Register 58: 4601-4614. 
Ayres, M.; Ayres, M. J.; Ayres, D. L. \& Santos, S. A. 2007. Bioestat 5.0: aplicações estatísticas nas áreas das ciências biológicas e médicas. Brasília, Sociedade Civil Mamirauá, CNPq.

Bandara, R. \& Tisdell, C. 2004. The net benefit of saving the Asian elephant: a policy and contingent valuation study. Ecological Economics 48: 93-107.

Bateman, I.J. \& Mawby, J. 2004. First impressions count: interviewer appearance and information affects in stated preference studies. Ecological Economics 49: 47-55.

Braga, P.l.S. \& Abdallah, P.R. 2003. Valoração contingente - estudo de caso: estação ecológica do Taim, RS. http://www.ceema.furg.br/ paolacadma.pdf. (Acesso em novembro de 2007).

Brandão, M. 1992. Plantas produtoras de taninos nos cerrados mineiros. Informe Agropecuário 16: 33-35.

Chaves, M.C.; Santos, F.A.; Menezes, A.M.S. \& Rao, V.S.N. 1998. Experimental evaluation of Myracrocruon urundeuva bark extract for antidiarrheal activity. Phytotherapy Activity 12: 549-552.

Cunningham, A.B. 2001. Etnobotánica aplicada. Pueblos, uso de plantas silvestres y conservación. Nordan Comunidad.

Desmarchelier, C.; Romão, R.L.; Coussio, J. \& Ciccia, G. 1999. Antioxidant and free radical scavenging activities in extracts from medicinal trees used in the 'Caatinga' region in northeastern. Journal of Ethnopharmacology 67: 69-77.

Edwards, P.J. \& Abivardi, C. 1998. The value of biodiversity: where ecology and economy blend. Biological Conservation 83: 239-246.

Fernandez, R.N. \& Kuwahara, M.Y. 2005. O valor econômico dos recursos hídricos no uso turístico: o exemplo de Brotas. VI Encontro da Sociedade Brasileira de Economia Ecológica, "O Meio Ambiente nas Políticas Públicas”. http://www4.mackenzie.com.br/fileadmin/ Graduacao/CCSA/Publicacoes/Jovens_Pesquisadores/04/3.4.13.pdf. (Acesso em novembro de 2007).

Fonseca, S.M. \& Drummond, J.A. 2003. O valor de existência de um ecossistema costeiro tropical através da disposição ao trabalho voluntário: o caso da Lagoa de Itaipu (Niterói, RJ). Ambiente \& Sociedade 5: 85-107.

Hildebrandt, E.; Graça, L.R. \& Hoeflich, V.A. 2002. "Valoração contingente" na avaliação econômica de áreas verdes urbanas. Floresta 32(1): 121-132.

Instituto Brasileiro de Geografia e Estatística (IBGE). http://www.ibge.gov. br. (Acessado em Setembro de 2008).

Instituto Brasileiro do Meio Ambiente e dos Recursos Naturais Renováveis (IBAMA). http://www.ibama.gov.br/flora/extincao.htm. (Acessado em Setembro de 2008)

Instituto do Patrimônio Histórico e Artístico Nacional (IPHAN). Availability: http://portal.iphan.gov.br. (Acessado em Setembro de 2008).

Kniivila, M. 2006. Users and non-users of conservation areas: Are there differences in WTP, motives and the validity of responses in CVM surveys? Ecological Economics 59: 530-539.

Leite, E.J. 2002. State-of-knowledge on Myracrodruon urundeuva Fr. Allemão (Anacardiaceae) for genetic conservation in Brazil. Perspectives in Plant Ecology, Evolution and Systematics 5: 193-206.

Lucena, R.F.P.; Nascimento, V.T.; Araújo, E.L. \& Albuquerque, U.P. 2008. Local uses of native plants in an area of caatinga vegetation (Pernambuco, NE Brazil). Ethnobotany Research and Applications 6: 3-13.

Marta-Pedroso, C.; Freitas, H. \& Domingos, T. 2007. Testing for the survey mode effect on contingent valuation data quality: A case study of web based versus in-person interviews. Ecological Economics 62: $388-398$

Mattos, A.D.M.; Jacovine, L.A.G.; Valverde, S.R.; Souza, A.L.; Silva, M.L. \& Lima, J.E. 2007. Valoração ambiental de áreas de preservação permanente da microbacia do Ribeirão São Bartolomeu no município de Viçosa, MG. Revista Árvore 31: 347-353.

Mattos, K.M.C. \& Mattos, A. 2004. Valoração econômica do meio ambiente: uma abordagem teórica e prática. Ed. Rima, Fapesp.

Máximo, P.S.; Silva, M.L. \& Máximo, M.S. 2009. Valoração de contingente pelas modelagens logit e análise multivariada: um estudo de caso da disposição a aceitar compensação dos cafeicultores vinculados ao Pro-Café de Viçosa- MG. Revista Árvore 33(6): 1149-1157.

Melo, J.G.; Amorim, E.L.C. \& Albuquerque, U.P. 2009. Native medicinal plants commercialized in Brazil - priorities for conservation. Environmental Monitoring and Assessment 156: 567-580.

MMA. Instrução Normativa No 6. http: www.mma.gov.br/ (Acesso em: novembro de 2008).
Montgomery, C.A. \& Helvoigt, T.L. 2006. Changes in attitudes importance of and willingness to pay for salmon recovery in Oregon. Journal of Environmental Management 78: 330-340.

Monteiro, J.M.; Albuquerque, U.P.; Lins Neto, E.M.F.; Araújo, E.L. \& Amorim, E.L.C. 2006. Use patterns and knowledge of medicinal species among two rural communities in Brazil's semi-arid northeastern region. Journal of Ethnopharmacology 105: 173-186.

Morais, S.A.L.; Nascimento, E.A. \& Queiroz, C.R.A.A. 1999. Studies on polyphenols and lignin of Astronium urundeuva wood. Journal of Brazilian Chemical Society 10: 447-452.

Mota, J.A. 2001. O valor da natureza: economia e política dos recursos naturais. Rio de Janeiro, Editora Garamond.

Motta, R.S. 2006. Economia Ambiental. Rio de Janeiro, FGV Editora.

Moura, L.A.A. 2003. Economia ambiental: gestão de custos e investimentos. 2 ed. São Paulo, Editora Juarez de Oliveira.

Nogueira, J.M. \& Medeiros, M.A.A. 1999. Quanto vale aquilo que não tem valor? Valor de existência, economia e meio ambiente. Cadernos de Ciência e Tecnologia 16: 59-83.

Oliveira, R.L.C.; Lins, E.M.F.; Araújo, E.L. \& Albuquerque, U.P. 2007. Conservation priorities and population structure of woody medicinal plants in an area of caatinga vegetation (Pernambuco State, NE Brazil). Environmental Monitoring and Assessment 132: 189-206.

Ortiz, R.A. 2003. Valoração econômica ambiental. Pp. 81-99. In: May, P.H.; Lustosa, M.C. \& Vinha, V. (Orgs). Economia do meio ambiente: teoria e prática. Rio de Janeiro, Editora Campus.

Pereira, P.F.S. \& Campos, E.M.G. 2005. Valorando o ecoturismo e as atividades recreacionais da área de proteção ambiental Serra de São José (MG): uma aplicação do método custo de viagem e da valoração contingente. Anais da 58 ${ }^{\text {a }}$ Reunião Anual da SBPC - Florianópolis, SC - Julho/2006. http://www.cedeplar.ufmg.br/seminarios/seminario_ diamantina/2006/D06A081.pdf. (Acesso em novembro de 2007).

Prefeitura de Caruaru. http://www.caruaru.pe.gov.br. (Acesso em Setembro de 2008).

Queiroz, C.R.A.A.; Morais, S.A.L. \& Nascimento, E.A. 2002. Caracterização dos taninos da aroeira-preta (Myracrodruon urundeuva). Revista Árvore 26: 485-492.

Ramos, M.A.; Medeiros, P.M.; Almeida, A.L.S.; Feliciano, A.L.P. \& Albuquerque, U.P. 2008. Use and knowledge of fuelwood in an area of Caatinga vegetation in NE Brasil. Biomass and Bioenergy 32: 510-517.

Rodal, M.J.N. \& Sampaio, E.V.S.B. 2002. A vegetação do bioma caatinga. Pp. 11-25. In: Sampaio, E.V.S.B., Giulietti, A.M., Virgínio, J., C.F.L. GamarraRojas (Eds.). Vegetação e flora da caatinga. Recife, APNE - CNIP.

Romeiro, A.R. 2003. Introdução. Economia ou economia política da sustentabilidade. Pp. 01-29. In: P.H. May, M.C. Lustosa, V. Vinha (Orgs). Economia do meio ambiente: teoria e prática. Rio de Janeiro, Editora Campus.

Sattout, E.J.; Talhouk, S.N. \& Caligari, P.D.S. 2007. Economic value of cedar relics in Lebanon: An application of contingent valuation method for conservation. Ecological Economics 61: 315-322.

Sanchéz, M. \& Pérez, L.P. 2000. Análisis conjunto y gestión pública de espacios protegidos: una aplicación al Parque Natural de Gorbea. Hacienda Pública Espanõla 153: 117-130.

Santin, D.A. \& Leitão, H.F.F. 1991. Restabelecimento e revisão taxonômica do gênero Myracrodruon Freire Allemão (Anacardiaceae). Revista Brasileira de Botânica 14: 133-145.

Silva, R.G. \& Lima, J.E., 2004. Valoração contingente do Parque "Chico Mendes": uma aplicação probabilística do método referendum com bidding games. Revista de Economia e Sociologia Rural 42: 685-708.

Venkatachalam, L. 2004. The contingent valuation method: a review. Environmental Impact Assessment Review 24: 89-124.

Viana, G.S.B.; Bandeira, M.A.M.; Moura, L.C.; Souza-Filho, M.V.P.; Matos, F.J.A. \& Ribeiro R. A. 2003. Analgesic and antiinflammatory effects of the tannin fraction from Myracrodruon urundeuva Fr. All. Phytotherapy Research 11: 118-12

Vieira, R.F.; Silva, S.R.; Alves, R.B.N.; Silva, D.B.; Wetzel, M.M.V.S.; Dias, T.A.B.; Udry, M.C. \& Martins, R.C. 2002. Estratégias para conservação e manejo de recursos genéticos de plantas medicinais e aromáticas: Resultados da $1^{a}$ Reunião Técnica. Brasília, Embrapa/Ibama/CNPq.

White, P.C.L.; Bennett, A.C.; Hayes, E.J.V. 2001. The use of willingness to pay approaches in mammal conservation. Mammal Review 31(2): 151-167. 